\title{
GÖRDÜLŐCSAPÁGYAK ÉLETCIKLUSÁNAK VIZSGÁLATA
}

\author{
Tóth Dániel \\ tanársegéd, Miskolci Egyetem \\ Szerszámgépészeti és Mechatronikai Intézet, Szerszámgépek Intézeti Tanszéke \\ 3515 Miskolc, Miskolc-Egyetemváros, e-mail: toth.daniel@uni-miskolc.hu
}

\begin{abstract}
Absztrakt
A csapágyak széles körben alkalmazott gépelemek. A müködési tulajdonságaik hatással vannak a teljes gép müködésére, ezért a vizsgálatuk kiemelt fontosságú témakör. Jelen cikk egy gördülöcsapágy teljes életciklusának rezgésdiagnosztikai vizsgálatával foglalkozik.
\end{abstract}

Kulcsszavak: gördülöcsapágy, élettartam, rezgésdiagnosztika

\begin{abstract}
Bearings are one of the most widely used machine elements. Their operating properties impact the function of the whole machine, therefore their investigation is very important topic. The following paper deals with complete lifetime analysis of rolling element bearings using vibrational diagnostic methods.
\end{abstract}

Keywords: rolling element bearing, lifetime, vibration diagnostic

\section{Bevezetés}

A csapágyak tulajdonságai az elhasználódásuk előrehaladtával változnak. Ezen tulajdonságok változása utalhat a csapágy maradó élettartamára. A kurrens élettartam rezgésdiagnosztikai eszközökkel is megállapítható. A gördülöcsapágyak rezgésdiagnosztikai vizsgálataira különféle, idő- és frekvenciatartományon elvégezhető jelanalizálási technikák léteznek. A spektrumanalízis az egyik leghatékonyabb módszer ezek közül. A gördülőcsapágyak azzal az alapvető mechanikai tulajdonsággal rendelkeznek, hogy leginkább egy-egy bizonyos frekvencián képesek adott irányokban rezgést végezni. Ezek a jellegzetes frekvenciák a felvett rezgésjel spektrumanalízisével beazonosíthatók, és az aktuális csapágyfordulatszám figyelembevételével hozzárendelhetők csapágyalkatrészekhez. E jellegzetes frekvenciákon kibocsájtott rezgési energia a defektus megjelenése és továbbfejlődése esetén megváltozik és ez a spektrumban is megjelenik [1].

\section{Vizsgálóberendezés}

Csapágyak állapotfelmérése kísérleti úton vizsgálóberendezés segítségével végezhető. A csapágyfárasztógépek fejlesztésének egyik fó iránya olyan gép tervezése, amellyel megfelelő befogószerkezetek, a gép fogadó felületeire felszerelhető kisegítő gépegységek, állványok segítségével a legkülönfélébb vagy kizárólag egyféle gépelemek fárasztása elvégezhető. Az alkatrészek befogására különös gondot kell fordítani, hogy a befogási hely a fárasztóvizsgálatokat ne zavarja, a terhelés átadása és maga a terhelés üzemi körülményeknek megfeleljen. Gondolni kell arra is, hogy a befogott és fárasz- 
tott alkatrész olyan rezgésbe ne jöjjön, amely az üzemi terhelésben nem jelentkezik [2]. Egy vizsgálóberendezés található a Miskolci Egyetem, Szerszámgépek Intézeti Tanszékén. A vizsgálóberendezés alkalmas csapágyak fárasztására és rezgésvizsgálatra egyaránt. A berendezés fö egységeit az 1. ábra mutatja.

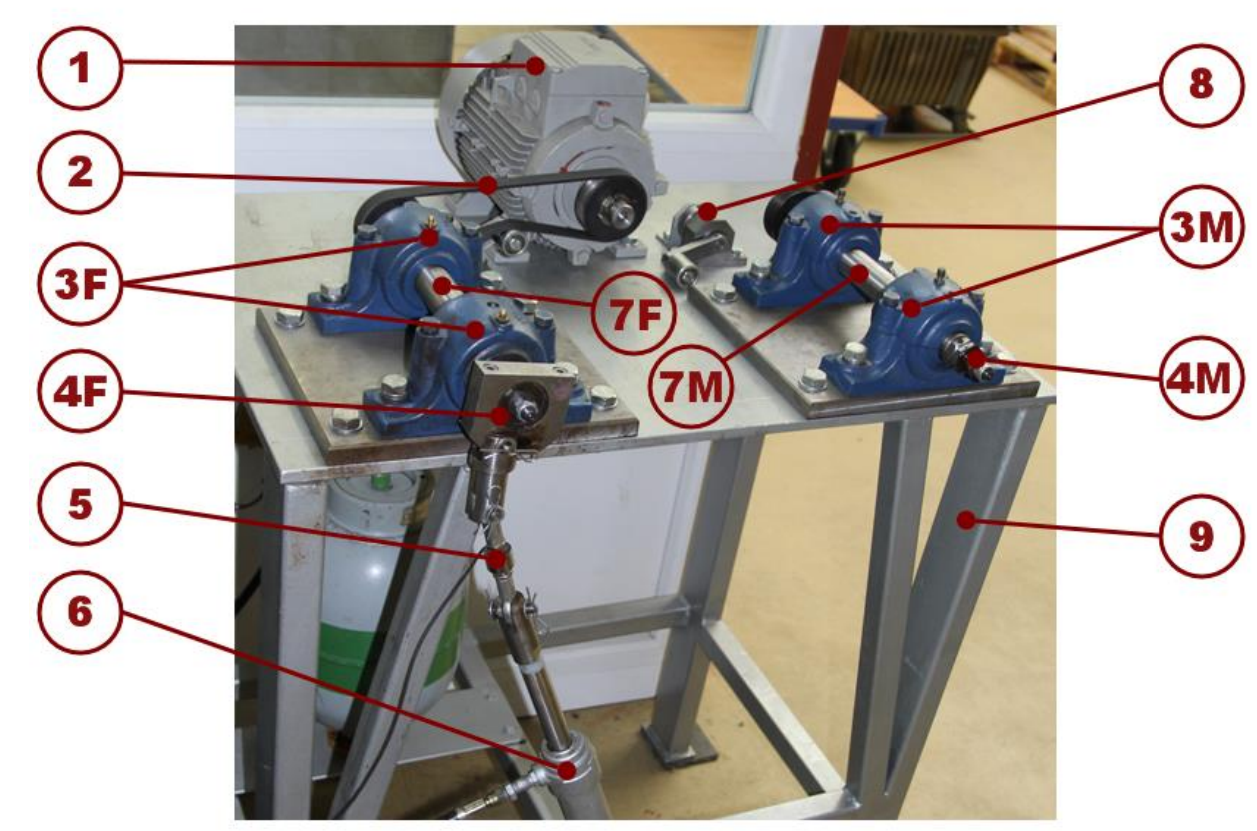

1. ábra. Csapágyvizsgáló berendezés

Az egyes rövidítések és jelölések jelentése a következő:

- 1 háromfázisú motor;

- 2 hosszbordázott szíjhajtás;

- 3F fárasztókészülék szerelt csapágyazása;

- 3M mérőkészülék szerelt csapágyazása különleges siklócsapágyazással;

- 4F fárasztandó csapágy;

- 4M mérendő csapágy helye;

- 5 erőmérő a hidraulikus terhelés beállításához;

- 6 kettősmüködésủ hidraulikus munkahenger;

- 7F fárasztókészülék tengelye;

- $7 \mathrm{M}$ mérőkészülék tengelye;

- 8 szíjfeszítő készülék a hosszbordázott szíjhajtás előfeszítéséhez;

- 9 merevített asztal.

A vizsgált csapágy fárasztása során a fárasztótengely (7F) müködik adott fordulatszámon, miközben a tengely csapjára szerelt csapágyra (4F) a hidraulikus henger (6) az erőmérőn (5) beállított müterhelést fejt ki egy kengyelen keresztül. Adott idejü fárasztást követően a vizsgált csapágyat (4F) tartalmazó kengyelt a hidraulikus henger (6) átbillentésével a mérőtengely csapjára (7M) erősíthető és 
ekkor a vizsgált csapágy pozícióba (4M) kerül, ahol rezgésmérés végezhető adott terhelőerő mellett. A mérések során a hidraulikus munkahenger $1[\mathrm{kN}]$ müterhelést fejt ki, míg a vizsgálóorsó 1500 [min $\left.{ }^{-1}\right]$ fordulatszámon müködik.

\section{Csapágyélettartam}

A csapágyak véges élettartamát olyan tényezőkkel lehet összefüggésbe hozni, mint például a fordulatszám, a kenési állapot, a terhelés, és a hőmérséklet. Az az időtartam, amíg az anyagfáradás első jele megjelenik, függvénye a terhelés nagyságának és a csapágy megtett fordulatainak. Ha a fordulatszám állandó, a csapágy névleges élettartama kifejezhetö üzemórákban [3]:

$$
L_{10 h}=\frac{10^{6}}{60 \cdot n} \cdot\left(\frac{C}{P}\right)^{p}
$$

ahol:

- $\mathrm{L}_{10 \mathrm{~h}}$ az élettartam [h];

- n a fordulatszám [1/min];

- C dinamikus alapterhelés [N];

- P ekvivalens dinamikus csapágyterhelés [N];

- p az élettartam kitevő, tapasztalati képlet alapján golyóscsapágyakra p=3.

Az előzőekben ismertetett csapágyvizsgáló berendezés segítségével, egy FAG 6303 típusú, egysoros, mélyhornyú golyóscsapágyat vizsgáltam. A kísérletek során mind a fárasztási, mind pedig a méröfordulatszám $1500\left[\mathrm{~min}^{-1}\right]$. A csapágyra a hidraulikus terhelökör segítségével $6000[\mathrm{~N}]$ terhelés lett beállítva. Az általam vizsgált golyóscsapágy dinamikus alapterhelés értéke 14400 [N]. Ezekkel a paraméterekkel a csapágy élettartama a következőképpen alakul:

$$
L_{10 h}=\frac{10^{6}}{60 \cdot n} \cdot\left(\frac{C}{P}\right)^{p}=\frac{10^{6}}{60 \cdot 1500[1 / \min ]} \cdot\left(\frac{14400[N]}{6000[N]}\right)^{3}=153,6[h]
$$

Megállapítható tehát, hogy a vizsgált FAG 6303 típusú csapágy az adott körülmények között várhatóan 153,6 óra élettartammal rendelkezik.

\section{Rezgésdiagnosztikai vizsgálatok}

A rezgésdiagnosztika alkalmazásával a szerkezet megbontása vagy leállítása nélkül bármikor megállapítható a kérdéses egység várható élettartama, károsodásának mértéke, pillanatnyi állapota, majd ezek alapján egy esetleges beavatkozás szükségessége és ennek időpontja az üzemeltetés függvényében [4]. A kísérletek során először rezgésmintát vettem a vizsgált (6303 típusú) csapágyról hibamentes állapotban. Ezt követően kezdődött a csapágy fárasztása, majd a határozott idejü (3-4 órás) fárasztási ciklusokat követően ismét rezgésmérés következett. A méréshez Kistler 8632C50 típusú, piezoelektromos rezgés-gyorsulásmérő szenzort használtam. A mintavételi frekvencia 9,6 [kHz], míg a minták elemszáma 16384 volt. A kiértékeléshez a Maple matematikai szoftverben írt programkódot használtam, ennek segítségével a rögzített adatok kiértékelését időtartományon és frekvenciatartományon is elvé- 
geztem. A rögzített rezgésminták spektrum formájú ábrázolásához gyors Fourier-transzformációt alkalmaztam. A csapágy „öregedésével” párhuzamosan a hibafrekvenciák egyre több felharmonikusa jelent meg, s ezek értékei exponenciálisan nőttek. A legnagyobb változást a kosár hibafrekvencia (FTF) felharmonikusai adták (2. ábra). Az előzetesen számított élettartam határán, rezgésspektrumban a hibafrekvencia csúcsok már jól elkülöníthetővé váltak.

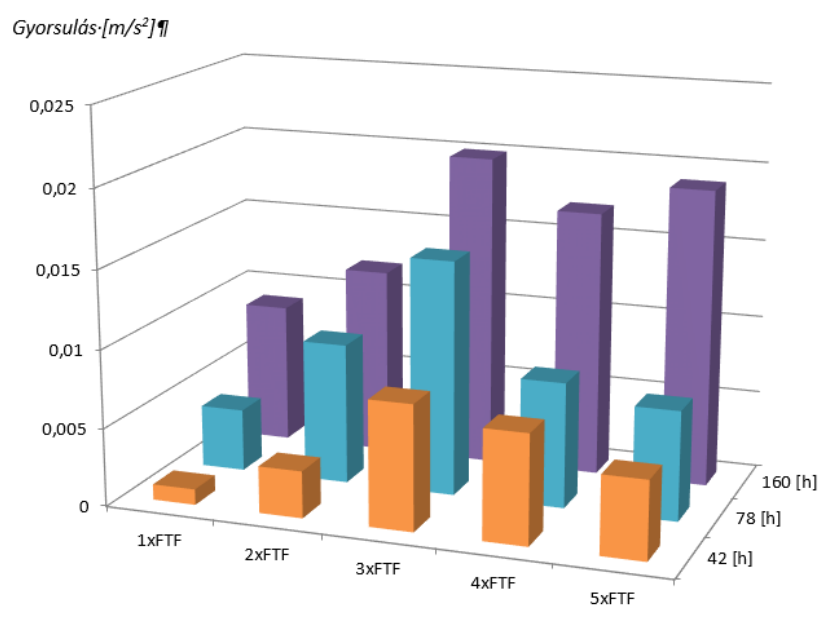

2. ábra. Kosár hibafrekvencia (FTF) változása a fárasztási idö függvényében

A mintavételezett értékek alapján statisztikai indexeket (Crest-faktor, RMS, Peak) számítottam, amelyek időbeli függése alapján kirajzolódó görbe jelenti az élettartamgörbét. A vizsgált csapágy élettartamgörbéi a kiszámolt jellemzők segítségével ábrázolhatók. Kifejezetten a csapágyban megjelenő defektusok kimutatására használt sztochasztikus index a Crest-tényező, amelynek alakulása a 3. ábrán figyelhető meg. Egyes szerzők szerint [5, 6], amennyiben az 5-ös értéket meghaladja a Crest-faktor, akkor nagy a csapágyon belüli defektus előfordulásának az esélye.

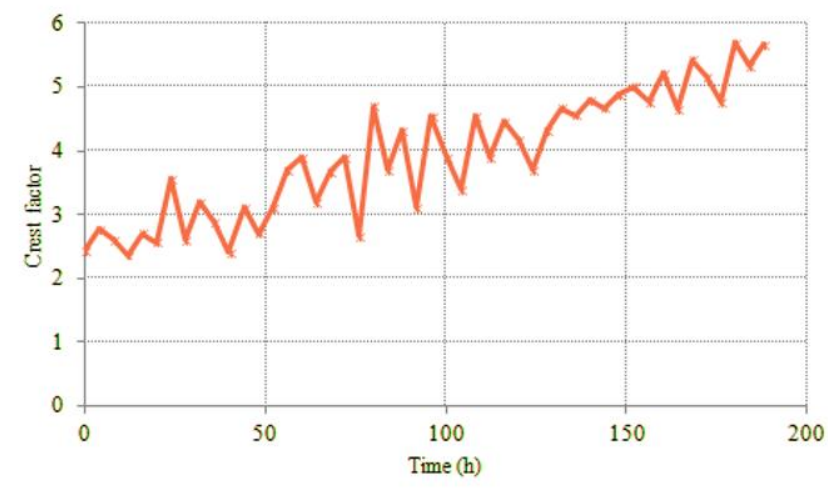

3. ábra. Crest tényezö változása

A csapágy fárasztása során a 171. üzemóra tájékán jelentősen megnövekedtek a hibafrekvenciák, emellett erősödő csapágyzaj is megfigyelhető volt. Ennek hatására, és a biztonsági előírásokat szem előtt tartva a csapágyat kiszereltük és a vizsgálatok befejeződtek. Amint az a spektrális elemzések eredményeiből is várható volt, a vizsgált csapágy tönkremenetelének fő oka a kosárszerkezet károsodása okozta. A csapágy kosárszerkezete a következő ábrán látható. 


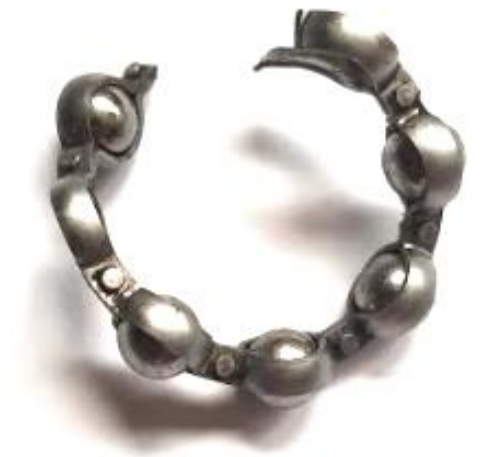

4. ábra. A károsodott kosárszerkezet

\section{5. Összefoglalás}

Jelen cikk keretei között a csapágyfárasztások által mélyreható diagnosztikai vizsgálatokat végeztem, melynek során a különbözö életszakaszokból vett rezgésspektrumokat értékeltem, valamint sztochasztikus jellemzőket számítottam. A meghibásodásra utaló jelek felléptekor a csapágy kiszerelésre került. A csapágyhibák feltárása után megbizonyosodtam a mérések által elörejelzett tönkremenetelről és egyben arról is, hogy a rezgésdiagnosztikai módszerek hatékonyan alkalmazhatók a csapágyállapot megítélésére.

\section{Köszönetnyilvánítás}

A cikkben ismertetett kutató munka az EFOP-3.6.1-16-2016-00011 jelü „Fiatalodó és Megújuló Egyetem - Innovatív Tudásváros - a Miskolci Egyetem intelligens szakosodást szolgáló intézményi fejlesztése" projekt részeként - a Széchenyi 2020 keretében - az Európai Unió támogatásával, az Európai Szociális Alap társfinanszírozásával valósul meg.

\section{Irodalom}

[1] Dömötör, F.: Rezgésdiagnosztika I. Dunaújváros, 2008.

[2] Tóth, D., Takács, Gy., Szilágyi, A.: Csapágyvizsgáló berendezés funkcióstruktúrái. Multidiszciplináris Tudományok: A Miskolci Egyetem közleménye 10: 4 pp. 45-49. 2020. https://doi.org/10.35925/j.multi.2020.4.7

[3] Bejzelman, R. D., Cipkin, B. V.: Gördülöcsapágyak kézikönyv. Nehézipari Könyv és Folyóiratkiadó Vállalat, Budapest, 1953.

[4] Patkó, Gy., Takács, Gy., Barna, B., Demeter, P., Hegedús, Gy., Barak, A.: A process for establishing the remanent lifetime of rolling element bearings. MicroCAD 2010: XXIV. microCad International Scientific Conference: Section L: Machine and structure design, Miskolc, Hungary: University of Miskolc, pp. 53-58., 2010. https://doi.org/10.1016/j.triboint.2008.11.003

[5] Karacy, T., Akturk, N.: Experimental diagnostics of ball bearings using statistical and spectral methods, Tribology International, 42, 836-843, 2009.

[6] Tóth, L.: Tranziens és kváziperiodikus folyamatok analizise az idö-frekvencia tartományban. PhD értekezés, Miskolc, 2011. 